\title{
On the Volunteers and Volunteering: The Case of Russia
}

\author{
Oleg N. Yanitsky \\ Federal Center of Theoretical and Applied Sociology of the Russian Academy of Sciences, Moscow, Russia \\ Email: oleg.yanitsky@yandex.ru
}

How to cite this paper: Yanitsky, O. N. (2020). On the Volunteers and Volunteering: The Case of Russia. Creative Education, 11, 307-320.

https://doi.org/10.4236/ce.2020.113024

Received: January 19, 2020

Accepted: March 14, 2020

Published: March 17, 2020

Copyright (c) 2020 by author(s) and Scientific Research Publishing Inc. This work is licensed under the Creative Commons Attribution International License (CC BY 4.0).

http://creativecommons.org/licenses/by/4.0/ (c) (i) Open Access

\begin{abstract}
The project mentioned below is aimed at the study of a possibility and forms of the civic volunteers' participation in a mitigation or prediction of modern natural and environmental disasters in Russia. Such participation is necessary taking into account the huge size of its territory and variety of natural and built landscape as well as of types of small settlements including the nomadic ones. In spite of very shaky Russian history of the XX century there were a diversity of types of the state and civil society's voluntary organizations. From the 1960s and up to now the environmental movement and its local grassroots and NGOs existed throughout the USSR/Russia's territory. Nowadays, the interest of lay people to the state and prospects of their living environment is rapidly growing especially due to the emergence of a global network structure. The global world is becoming more unstable, unpredictable and therefore more risky, be it natural, social or artificially-constructed. The process of a gradual transformation of the biosphere into a sociobiotechnical sphere is rapidly going on. As social and natural sciences continue to develop separately, the citizen's social science began quickly developing both in many parts of Russia and across the world, and the volunteer's units took an active part in that process. The standard modes of rescuers' activity came into contradiction with our movable and unpredictable world. Under such conditions the volunteers should be not only well-experienced but interdisciplinary specialists able to translate from one language, say local nomad people into two-three scientific languages.
\end{abstract}

\section{Keywords}

Citizen Science, Civil And State Volunteers, Environmental Challenges, Global Network Structure, Natural Sciences, Russia

\section{Introduction: Why This Risky Institution Is Necessary to Study?}

The abovementioned project is aimed at study of a possibility and forms of the 
volunteer's participation in a mitigation or prediction of modern natural and environmental disasters. In Russia up to now the rescue operations are usually fulfilled by the forces of the Ministry of the Emergency Situations. At the same time, the volunteer's participation in such operations is slowly but persistently widening especially in the cases of small country's settlements. Our country is so large that the town planners offered to qualify these remote settlements and provinces as situated in the Deep Russia. Besides, as sometimes happened, these remote places are hardly accessible for large planes and helicopters. Or their use seems economically inefficient.

But the similar situations are peculiar to many other parts of our planet. At the same time, due to the emergence of the "Internet Galaxy", on the one hand, and the rising of amount of well-informed and well-educated of the world's population, on the other hand, an interest of the lay people to the state and prospects of their living environment is rapidly growing. At the same time, by and large, the global world is becoming more unstable, unpredictable and therefore more risky, be it natural, social or artificially-constructed. The very fact of a gradual transformation of the biosphere into a sociobiotechnical sphere (hereafter the SBT-system) with its unknown regularities and unpredictable transformations clearly points out to the fact of a sudden emergence of numerous critical situations here and there.

After the collapse of the USSR and the beginning of Russia's transition to market economy, a risk of emergence of numerous critical situations has grown enormously. There is a principled difference between an "accident" (Perrow, 1984) and the critical situation (Pinnoniemi, 2012; Yanitsky, 2014b). The former is a true particular accident within a more or less stable functioning of the social institutions of a particular society.

In sum, in spite of any state creates its own rescue forces, the risky situations (accidents, natural disasters and their social and environmental consequences, technological catastrophes) require various forms of citizen's mobilization which gradually transforms into civil rescue groups and charity organizations. It's rather indicative that the idea of citizen social science has simultaneously emerged both in many parts of our world including Russia. It has been a predictable outcome of our simultaneously rapidly diversifying, integrating and unpredictable world. To my mind, nowadays the specialists in social sciences and humanities as well as the politicians have a right to speak about the emergence of a new type of the researches named as public-scientific research (Yanitsky, 2005, 2014a; Lidskog, 2008; Purdam, 2014). It doesn't mean that the difference between so-called local knowledge and a scientific one is totally effaced. Rather it's going on about the better understanding between them and more close collaboration in the making of the research projects.

\section{Volunteering in Russia/USSR/RF in the XX Century}

To my mind, the very term of the volunteering is too vide and therefore uncertain because it mat has a form of the grassroots, local activism of the particular 
persons, and various forms of environmental and other social movements. As I'd mentioned in my previous article, in the frames of our project we intend to study the various forms of volunteering in the cases of critical situations (hereafter the CS) of various forms that are happening in a diversity of contexts.

As we are intend to study the CS generated by current natural and technological disasters, a historical roots of volunteering in the Russia/USSR/RF is interesting for us form the viewpoint of evolution of this social institution. I convinced that in any historical period, the volunteering has been a particular institutional form of Russian civil society existence. Even in the most critical periods of Russia's history (the WWI and WWII, the civil war of the 1918-21, repressions, and the collapse of the Soviet Union) the various forms of civil society institutions have been existed. Even now in the times of a total domination of network structures, the cells of civil societies do exist but in the other forms. It allows me to state that the existence of like-minders is of a primary importance, and their structural-functional organization is secondary ones. It doesn't mean that the values and attitudes of such cells remains the same.

Conditionally, a development of civil society organizations (CSO) may by divided on the following periods. The first, pre-WWI times has been characterized by an emergence of a variety of the charity organizations and their opponents and the Ultra-Nationalist social movements like the Black Hundred, a populist, xenophobic, and profoundly anti-Semitic movement (Laqueur, 1993). The second period had been the times of the first Russian revolution (the 1904-07). It had been marked by a rapid growth of the trade unions and various workers' organizations that mainly had politically-enlightenment character.

The third period, the WWI, generated many legal and underground "cells" with openly political agendas. The fourth period, i.e. the February democratic revolution of the 1917, been characterized by a mixture of a great number of the politically left and right units. It's indicative that in the very beginning of the XX century the Howard's idea of the "Garden cities of Tomorrow" had been considered both by the liberals and communist as mean of resolving social contradictions of any kind (Howard, 1902). By the way, after the Great October revolution of the 1917 the communist's leaders many times attempted to realize the Howard's idea in practice.

The fifth period is the civil war of the 1918-21 which had been marked by the chaos of temporary diversity of small groups on two polar trends, a constructive and destructive. This civil war as it is had represented itself a variety of numerous small groups which compete with each other. The sixth period, the 1920s was the period of a social constructivism and futurism. It had been the times of an outburst of social creativity of all social groups of the Soviet Union. The peak of this outburst was the discussion on a future of socialist city (Kopp, 1967). This period may be named as the last attempt of Russian and foreign intelligentsia to find a balance between the left and the right as well as between the already existing civil society and the shaping authoritarian socialist state. At the same time the communist leaders began a process of converting of numerous of the gras- 
sroots and creative groups of Russian intelligentsia into the centralized unions of the artists, architects, composers, cinematographers, painters, etc.

It's interesting that in parallel with such discussions the Soviet Union intensively constructed its biggest industrial cities as Magnitogorsk, Nizhnyi Novgorod and Chel'yabinsk (see for example, Kotkin, 1991).

The seventh period had begun after the end of the WWII. When the Great patriotic war of the 1941-45 had ended, an intensive period of rehabilitation of territories temporary occupied by the fascist armies had begun. Once again the joint efforts of the state and civil society organizations have been needed. In those times two forms of volunteering were usually existed. The former were the members of many state-supported civil organizations while the latter were self-organized initiative groups. For example, many ad hoc groups of inventors and rationalizers of industrial workers had emerged. I'd like to underscore that in those times an overwhelming majority of the Soviet people including the teenagers and aged had been extremely experienced people. This socio-cultural archetype of man had been a heritage of the former peasant Russia. At the same time the outstanding Russian writers, so-called "writers-villagers" as G. Abramov, V. Belov, V. Rasputin, Vl. Tendri'yakov and many others draw a public attention to the environmental risks and threats of large industrial projects, first of all of the construction of the hydropower stations.

The eighth period (the1955-60s) had been marked by a contradictory combination of large industrial projects including a mastering of a virgin and long-fallow lands and the emergence of numerous civil initiatives within state-established public organizations. To my mind, it had been a kind of a peaceful revolution from below. For example, the searches for an ideal habitat unit (a neighborhood, an ideal model of a future socialist city) had been resumed again.

The ninth period (the 1960-90s) had been the times of a sustainable growth of social and environmental initiatives from below and the beginning of the shaping of proto-political movements and parties. A great institutional turn has matured.

The tenth period, i.e. the perestroika years (the 1988-91) had been the peak of social activity from below, especially in the realm of environmental protection. It was the times of great wishes and hopes and political activity of masses (see details in: Yanitsky, 1996, 1999).

The eleventh period (the 1991-96) had been the times of radical institutional transformation burdened by the sharp decline of the living standards of a majority of a newly emerged Russian Federation. But once again, a majority of lay people could survive due to their "social genetics" i.e. a potential of surviving of the experienced men in the critical conditions. It's indicative that almost all members of Russian environmental movement are not only survived but had protected their knowledge and experience accumulated in the previous years.

The current twelfth period is a transition toward the Fourth Industrial Revolution (hereafter the STR-4) or using the Castells definition (2004) toward the 
“Internet galaxy." Later on, I've stated that such shift will trigger a set of complex transformations in all spheres of Russia's life including the relationships between the sciences, teaching and practice (Yanitsky, 2008, 2010) focusing on various metabolic processes between qualitatively different structures, processes and substances (Yanitsky, 2013).

In Russian official documents it is defined as a transition "On figure." But actually this turn toward the STR-4 signifies a necessity for initiate complex transformations in almost all spheres of an economy, politics and everyday social life. Unfortunately, there is still neither scientific nor public discussion concerning the social and environmental consequences of these transformations.

But another clear cut message has been recently made by Russian authorities: the RF state should be stronger in order to make our society safe from an outside interference of any kind. Does it mean that the volunteers and their organizations will be eliminated from the coping with any emergency or extreme situations? To my mind, doesn't because our world as a whole has entered in a very risky period of its development for many reasons. The risks of the STR-4 epoch are quick, not predictable, and due to the global network structure are all-embracing and all-penetrating. As I'd already mentioned, the differences between peace and war, here and there, we and they etc. are quickly effaced. Thus, from time to time the lay people will be forcefully turned into the volunteers or the grassroots members.

The last but is not the least. As the Western politicians clearly showed, in the political science, interest groups theory recognized the importance of the type of relationships between the state agencies and the interest groups which are usually well-organized and experienced in their lobbying activity. Such relationships are divided into two main types: an acceptance and non-acceptance of the groups challenge. The former of the above type is presented as a pair of a full legitimation and cooptation, while the latter one as pre-emption and repression accordingly (see for example: Gamson, 1990, Chapter 3, pp. 32, 34, 37, 123 and many others). Russia is less politicized country but the above scheme is well-applicable to our conditions.

\section{Why the EM Has Been so Attractive and Efficient in the USSR and the RF?}

It's a kind of historical paradox: within very centralized institutional system of the USSR and then in the RF the environmental movement did exist in various forms: as the reserves, public societies, grassroots, and from the beginning of the 1960s till now as social movements aimed at a protection of man and nature.

I see at least three reasons of its viability. One is the EM and its cells had been a kind of "asylum" both for the scientists and scholars especially in the times of the persecution on genetics and later during the debates on the RF modernization (Yanitsky, 2005, 2008). As Russian outstanding scientist, one of the authors of the Biosphere concept acad. V. Vernadsky stressed that small scientific groups are of a great vitality. Later the US scientist D. Weiner fully confirmed this 
statement by means of the study of Russian archival materials (Weiner, 1988, 1999).

The second reason is that a young socialist society couldn't survive without such small groups and research institutions. Let me offer one example in which I'd been an involuntary witness. When J. Stalin dismissed an outstanding physicist, the future Noble laureate Piotr Kapitza from all his research positions, Kapitza built the small lab at his dacha's (summerhouse) plot and continued his experiments. The acad. Vernadsky had been the initiator of the Soviet uranium project.

The third reason was the so-called Stalin's plan of nature protection announced in the 1948 which initially had been based on the works of the well-known Russian biologists V. Dokuchaev, P. Kostychev and V. Williams in the 1940-50s years. The very idea of protection had relied upon two pillars: the forest shelter belts and grassland crop rotation. It had been the unique case when the interests of the Soviet leaders, scientists and ordinary people had been coincided. Besides, this plan had been widely propagated by the radio and press, and had been attractive to the schoolchildren especially in the countryside.

Then, after the decade the Soviet nature protection movement had been established (initially as the Students' nature protection movement, or the Druzhina movement in Russian) and it exists up to now while its aims and priorities gradually changed. Recently, following the national and global transformations it turned toward the studies of global warming processes, an influence of the turn on the G5 network system of communications as well as to the study of natural and health consequences of the wastes accumulation.

The viability of this movement had been conditioned by many factors. Firstly, it had been the EM relied upon triple institutions: a science, teachers and the students' community. Secondly, from the very beginning it had been a network organized social institution, initially based on face-to-face contacts, common actions and meetings, and then on the Internet communications. Thirdly, the Druzhina movement had been patronized by the teachers and scientists, but it has been very democratic contacts. Later on, the alumni of the universities and their postgraduates continued to participate in this movement. Fourthly, this movement has been especially attractive to the students from provincial universities because many of these students felt themselves as a part of the country's student community.

As the alumni of this movement stated, the Druzhina made them well-trained and self-sustained persons. It's indicative that in the hard years of perestroika all of the movement members not only survived but had become high-level specialists and well-experienced people.

More than that, the most talented its ex-participants has now become the leaders of a set of international research projects or/and the high-quality independent experts.

Nowadays, when the world environmental problems have become acute some of the scientific curators of the EM have become the environmental politicians, 
and the ordinary participants of the EM turned into the researchers. And by means of such reciprocating movement the EM reproduces itself and its ideas and members. And the other their achievement is a capability to join a general trends and particular cases. It's rather important for the development of the interdisciplinary approach.

\section{The Emergence of a Mass Society and Its Consciousness and Knowledge}

Until the perestroika beginning in the second half of the 1980s there was no mass society in the USSR because it has been a highly centralized society. The emergence of the mass society doesn't necessarily a product of the Western type of market economy and its mass-media let me remind the excellent work of D. Riesman the "Lonely Crowd" (Riesman et al., 1965). As one can recently see the events in the Livia and Lebanon, the mass protest movements which quickly turning into the civil wars is a specific form of the mass society phenomenon of many modern but still backward societies.

In the second half of the 1980s the USSR hadn't been the backward society. On the contrary, the 1960s and 1970s our country had experienced a rapid development of natural, technical and social sciences and had been prepared to launch a transition to market economy (Achiezer at al., 1969; Lisichkin, 1966).

To my mind, in the second half of the 1980s the perestroika began from the above that is in the interest of the Communist party officials and the shadow and underground millionaires. The destruction and not the renovation of the country's economy and its institutional structure had been launched. The leaders of the so-called colored revolution of the Baltic countries assisted in such distractive transformations (Lauristin \& Vihalemm, 1997).

Of course, in the period in question both an industry, institutional structure and the mode of living of ordinary people had serious shortcomings. But the sharp decline of living standards, unemployment and political chaos had been the main triggers of mass protest movements that undermined both the institutional basement of the USSR and provoked the emergence of mass protest movements. Besides, it's appeared that the aged Soviet Leaders were incapable to cope with such mass peaceful events.

In such shaky conditions any volunteering in the modern sense of the word had been impossible because it was the period of mass search of the means of survival. It's the survival was the main will and therefore slogan of mass Soviet society of that times. In other words, such unpredictable and radical decline of all socialist principles and norms coupled with unknown future had been a "natural" reaction of mass society on that perestroika. The "market revolution" made both by unskilled "market leaders" together with absolutely unprepared socially-disoriented rank-and-file population was not a good method of such radical change of economic and social pillars of the Soviet society. It's said to recognize that in those times the scientific model of a gradual transition from the 
state socialism toward the market capitalism didn't exist at all.

In sum, the perestroika had been the radical economic and political revolution of the rich minority masked by the democratic slogans addressed to the quite different, unprepared and disoriented masses of ordinary people. In those times I'd worked as a field sociologist fixing the attitudes and expectations both of the perestroika leaders and ordinary people (Yanitsky, 1991). It had been the period of the pipe-dreams of the insulted and injured masses of ordinary people.

\section{The Differences and Similarities between the State and Civil Society Volunteers}

It's not only sociological but an acute political issue. Recently, the state volunteers are selected, recruited and trained by state's professionals in the sphere of a maintenance and social order while the civil volunteers are the product of a good will of the civilians and their grassroots organizations. The former are hired and paid by the power structures whereas the latter usually self-organized, unpaid and shaped their teams mainly ad hoc. Let me then to compare the two types of the volunteers point by point.

Firstly, the state volunteers are used by the above powers for the maintenance of social order at the places of mass gatherings like the Olympic Games, football matches and mass meetings and processions. The realm of civil volunteers' activity is much more wide and diversified.

Secondly, the activity of the former category of the volunteers is guided by their organizers who defined whether a current situation is critical or not while the latter category defined a degree of risk and in accordance with it developing a strategy and tactics of their activity.

Thirdly, an activity of the former volunteers' group is defined by the power forces, and therefore I could to name them as a kind of the civil reservists. While the latter group acts independently if they think that natural or social subjects or ecosystems are urgently needed in an assistance or immediate help.

Fourthly, the former are followed the written instructions or/and oral commands of their organizers or the state's representatives while for the latter their rescue activity is a distinguishing feature of their mode of thinking and everyday activity. In essence the activity of the civil volunteers is a kind of creative work every time in a new critical and therefore risky situation.

Fifthly, accordingly the work of the former groups may be tense and hard but not risky one because they are always protected by police and army forces. The work of the latter one is really risky because the sometimes they are came into conflict with the state rescuers. Therefore, the civil volunteers should be always prepared to render help to their colleagues.

A capability for a self-organization in unknown and quickly changing situation is a distinguishing feature of the civil volunteers.

Sixthly, the work of the state volunteers is a regular or ad hoc source to gain some money and, may be, a possibility for making his/her further carrier. The activity of civil volunteers is a result of inner motives shaped by such factors as 
family upbringing, education, ethics of close friends, and as a result by his/her deep conviction what is right and what is wrong.

Finally, there is no an insuperable barrier between these two types of the volunteers. But a long-term playing the former or the latter role is shaped a type of a personality of the volunteer.

\section{The Case of a Mixt Type of the Volunteering}

There are at least three such types. The first one is a kind of complex and actually interdisciplinary type of the volunteering. The best examples of it are the international team the "Doctors without Borders," the "Barefoot doctors" from Cuba, the "Liza Alert" from Russia and many others. All such teams are really interdisciplinary, well trained and equipped groups of the doctors and other specialists which are capable to render help in a variety of critical situations. A quick mutual understanding is a distinguishing feature of such teams which can work in any point of the globe.

I'd like to stress that not all members of such teams are the doctors because their stuff should be able to deploy a field hospital, to teach the aboriginals of the $\mathrm{ABC}$ of rendering of the first aid and so on and so forth. Such teams' members are not the ad hoc volunteers-they are the volunteers by vocation. As many interviews with them shoved, it's their way of life, because they so deeply get in this role that their everyday mode of living seems to them as unattractive and even strange. During two years of the WWII my mother has been the head of the rear military hospital. Of course, it had been the quite another time and incomparable conditions but it's important to underscore that the thoughts and way of life of its personnel had been totally subjected to a particular conditions in situ. As I may judge by the memoirs of my grandfather, the field doctor Feodor Yanitsky (1852-1937), his mode of acting and living had been the same. To my mind, the doctors without border should now be in every country because such "critical type" of persons is needed to cope with a variety of accidents across the world in any time. It's one more example that recently the further the more a current state of living environment dictates where, when and what particular type of help is urgently needed.

The other mixed type of a volunteering is qualitatively different. It's a local and the ad hoc volunteers. It doesn't mean that they are worse or not needed. On the contrary, such local volunteers, if any, are playing very important roles. Firstly, they well acquainted with local situation in detail. Say, they are well informed about human and other resources necessary for coping with a particular critical situation. Secondly, they knew an actual state of local habitat and its surroundings. Thirdly, they well acquainted with local administration and their resources at hands. Fourthly, they well-informed when and what kind of help may be rendered by local and regional rescue forces in a due time, etc.

One more mixed type of the volunteering is the most problematic. I mean a degree of collaboration between the state rescue forces and local volunteers. 
From my viewpoint, the both sides are in a manner guilty. If the state rescuers came in time, they act strictly independently in accordance with their codes, protocols and instructions, often irrespectively of a specificity of local situation and its possible transformations. There is an obvious gap between fixed instructions and rapidly and often unpredictable transformations in situ. From the viewpoint of the state rescue forces are simply "local population" and not the potential or actual volunteers. In contrast to modern military forces which are now oriented to deal with hybrid and permanently and quickly changing circumstances the rescue forces are not oriented to act in a changing situation. In other words, their institutional structure begins to lag behind of regularly changing local conditions more and more.

In turn it means that the standard modes of rescuers' activity came into contradiction with our movable world. This is a very urgent issue of the theory and practice of coping or mitigation of critical situations because it means a growing gap between the material and virtual world and our perception of it. It signifies that all existing means of education and teaching, including the mass-media and social networks should assist to overcome this gap. Finally it appears that all rescue forces have to learn how to act in such movable and unpredictable world. In turn, a task to create the safe world is a permanently and therefore transformable issue. It's the key issue for the near future but the social sciences and humanities without a close collaboration of natural and technical sciences are not prepared to offer a decision. The only one is more or less clear: the existing forms of competition and struggle including the nuclear or biological arms races aren't the way out.

\section{Unstable and Risky World and the Prospects of the Volunteer's Movement}

Let's consider some of the above issues in detail. From the end of the WWII and further many researchers and politicians stated that the "new brave world" couldn't be permanently safe and calm. On the contrary, the further the more it is becoming more unstable, uncertain, unpredictable and therefore risky (Beck, 1992, 1999; Lupton, 1999; Yanitsky, 1999, Sagan, 1993). Recently, as U. Beck rightly stated, we are living in the world of the "after-effects" since a modern futurology doesn't exist at all. That is world society cannot be safe by definition because instability and unpredictability is profitable to the states, numerous business companies and rescue forces because it's their work to struggle with the consequences of various disasters.

Nevertheless, I think that the volunteers' and charity movements will remain in the foreseeable future. Firstly, no one society could exist without civil society, small and dependent but it will exist. Secondly, the assignments to charity and to other forms of civil activism are advantageous for business organizations because it is a mean to reduce their taxes. Thirdly, such assignments usually serve for raising the publicity of the donators. Fourthly, to meet a particular part of the requirements of civil organizations, and especially of the protestors is much 
cheaper than to convert their demands into long-time and sometimes contradictory parliament or state procedures.

The key issue both of state scientific institutions and of civil society initiatives and movements is their capability to predict the coming threats and risks. It's necessary to distinguish the risks, threats and disasters. The risk is a mental category which constructed by the scientists and scholars as a warning of an emergence of a particular threat. The threat is a kind of a double i.e. mental-and-practical notion signifying a possible set of various characteristics of that threat and its various after-effects. Under disaster I mean a calculation of actual and future damages in situ. Unfortunately, up to now the struggle against these damages begins within or after the already happened disaster. Finally, the matter is that every natural disaster or technological catastrophe usually has a cascade character, and its every next step may have its specific outcomes.

A kind of the volunteers' activity is dependent on many things: their access to the necessary information, resource supply, their own experience, the relationships with local residents and municipal authorities and many other ties and relations (see, for example: Murphy, 2009).

Finally, the abovementioned complex teams as the "Doctors without Borders", the "Lisa Alert" and many other Russian volunteers' teams clearly showed, the further the more any volunteer's activity acquires a multi-disciplinary character. It follows that the volunteers should be not only experienced but interdisciplinary specialists able to translate from one language, say local nomad people into two-three scientific languages. I'd like to reiterate that many Russian lay people sometimes much more experienced that their foreign colleagues.

In sum, the further the more in one way or another, the global social community has to bother about its own safety and survival at all levels of its structure, an individual, local, regional and global.

\section{Conclusion}

The global world is becoming more unstable, unpredictable and therefore more risky, be it natural, social or artificially-constructed. Plus the global transformations are permanently speeding up. Therefore, it's quite natural that not only international institutions and states but the shaping international civil society are bothered about their future.

The Russia's civil society isn't the exclusion. In spite of a set of critical events and institutional and other transformations, this civil society is existed and developed. The Russian history confirmed that the civil society cells and networks had been very resistant and viable irrespectively to any critical transformations. Vl. Vernadsky had been right: well-informed small scientific groups are of a great vitality.

The said above is fully related to the voluntary organizations and their everyday activity. The secret of their viability is rooted in their roles of the insiders and participants of everyday life of rank-and-file people. The volunteers and their local units are very sensitive to any critical events occurred in that life. It 
may be said that the volunteers' activity is a kind of indicator of quality of everyday life.

Recently, Russia is in the transition toward the STR-4 that generates permanent critical institutional transformations and structural-functional changes. The key issue both of state scientific institutions and of civil society initiatives and movements is their capability to predict the coming threats and risks. An issue of keeping the safety of our society and its sustainability come to the forefront. All rescue forces including the volunteers have to learn how to act in a movable and unpredictable world.

It is indicative that the International Socio-Ecological Union (the SoEU) had been established by the Soviet eco-activists in the 1988 i.e. more than twenty years ago. It means that the idea of a necessity of the interdisciplinary approach to the studies to environmental and other issues had emerged long before than in the Russian scientific community and the state's institutions. Nowadays, Russian volunteers are actively studying the possible threat of the use of human communications based on the G5 techniques and other possible critical transformations generated by the new technologies. It means that in the Digital era the environmentalism as the civil activism is again becoming a complex (interdisciplinary) social activity in which various age categories of population participate.

\section{Funding}

This article is funded by the Russian Scientific Fund, grant No 19-78-10052, the project "Emergency volunteering as a reply to the natural and technological challenges in Russia".

\section{Conflicts of Interest}

The authors declare no conflicts of interest regarding the publication of this paper.

\section{References}

Achiezer, A., Kogan, L., \& Yanitsky, O. (1969). Urbanization, Society, and the Scientific and Technological Revolution. Voprosy Philisofii, 2, 43-53 (In Russ.)

Beck, U. (1992). Risk Society. Toward a New Modernity(260 p.). London: SAGE.

Beck, U. (1999). World Risk Society (184 p.). Malden, MA: Polity Press.

Castells, M. (2004). The Internet Galaxy. Reflections on the Internet, Business, and Society(292 p.). Oxford: Oxford University Press.

Gamson, W. (1990). The Strategy of Social Protest (2nd ed., 185 p.) Belmont, CA: Wadsworth Publishing Company.

Howard, E. (1902). The Garden Cities of Tomorrow. London: Swan Sonnenschein \& Co.

Kopp, A. (1967). Ville et Revolution. Architecture et Urbanisme Sovietique des Annees Vingt. Paris: Edition Anthropos.

Kotkin, St. (1991). Steeltown, USSR: Soviet Society in Gorbachev Era (269 p.). Berkeley, CA: University of California Press. 
Laqueur, W. (1993). Black Hundred: The Rise of the Extreme Right in Russia (318 p.). Broadway, ’NY: Harper Collins Publishers.

Lauristin, M., \& Vihalemm, P. (1997). Return to the Western World. Cultural and Political Perspectives on the Post-Communist Transition (387 p.). Tartu: Estonian Science Foundation.

Lidskog, R. (2008). Scientised Citizens and Democratized Science. Re-Assessing the Expert-Lay Divide. Journal of Risk Research, 11, 69-86. https://doi.org/10.1080/13669870701521636

Lisichkin, G. (1966). Plan and Market Economy (96 p.). Moscow: Ekonomika. (In Russ.)

Lupton, D. (1999). Risk and Sociological Theory: New Directions and Perspectives. Cambridge: Cambridge University Press. https://doi.org/10.1017/CBO9780511520778

Murphy, R. (2009). Leadership in Disaster. Learning for a Future with Global Climate Change (406 p.). Montreal: McGill-Queen's University Press.

Perrow, Ch. (1984). The Normal Accidents. Living with High-Risk Technologies (168 p.). New York: Basic Books.

Pinnoniemi, K. (2012). Russian Critical Infrastructures. Vulnerabilities and Policies (119 p.). Tampere: The Finnish Institute of International Affairs.

Purdam, K. (2014). Citizen Social Science and Citizen Data? Methodological and Ethical Challenges for Social Research. Current Sociology, 62, 374-392. https://doi.org/10.1177/0011392114527997

Riesman, D., Glazer, N., \& Denney, R. (1965). The Lonely Crowd. The Study of the Changing American Character (315 p.). New Haven, CT \& London: Yale University Press.

Sagan, S. (1993). The Limits of Safety. Organizations, Accidents, and Nuclear Weapons (286 p.). Princeton, NJ: Princeton University Press.

Weiner, D. (1988). Models of Nature: Ecology, Conservation, and Cultural Revolution in Soviet Russia (312 p.). Bloomington: Indiana University Press.

Weiner, D. (1999). A Little Corner of Freedom. Russian Nature Protection from Stalin to Gorbachev (556 p.). Berkeley, Los Angeles, CA: University of California Press.

Yanitsky, O. (1991). Social Movements. One Hundred Interviews with Its Leaders (273 p.). Moscow: Moskowski Rabotchyi. (In Russ.)

Yanitsky, O. (1996). The Ecological Movement in Post-Totalitarian Russia: Some Conceptual Issues. Society and Natural Resources, 9, 65-76.

https://doi.org/10.1080/08941929609380952

Yanitsky, O. (1999). The Environmental Movement in a Hostile Context. The Case of Russia. International Sociology, 14, 157-172.

https://doi.org/10.1177/0268580999014002003

Yanitsky, O. (2005). Dialogue between Science and Society. Social Sciences. A Quarterly Journal of the Russian Acad. of Sciences, 36, 78-90.

Yanitsky, O. (2008). Modernization in Russia: Challenges to Research and Education. Moscow: Institute of Sociology.

Yanitsky, O. (2009). The Shift of Environmental Debates in Russia. Current Sociology, 57, 747-766. https://doi.org/10.1177/0011392109342202

Yanitsky, O. (2010). Russia's Changing World: Resources, Networks, Localities. Social Sciences. A Quarterly Journal of the Russian Academy of Sciences, 4, 103-122.

Yanitsky, O. (2013). Metabolicheskaya konseptsyia sovremennogo goroda [A Metabolic Concept of Modern City]. Sotsiologicheskaya nauka i sotsial'naya praktika, 2, 16-32. 
Yanitsky, O. (2014a). Sociology of Critical Areas. Open Journal of Social Science Research, 2, 112-118.

http://manuscript.sciknow.org/uploads/ojssr/pub/ojssr 140963345.pdf

Yanitsky, O. (2014b). Volunteers: Civil and State. Sotsiologicheskaya nauka i sotsial'naya praktika, 1, 71-89. 